\title{
SZERBIA ÉS KOSZOVÓ VISZONYA (2010 - 2020)
}

\author{
Relations between Serbia and Kosovo (2010 - 2020)
}

\section{Ördögh Tibor ${ }^{1}$}

\begin{abstract}
Absztrakt: Szerbia és Koszovó viszonyrendszere összetett. Tanulmányomban a 2008-tól napjainkig zajló események elemzésére törekszek, 1́gy a konfliktus 1980-as évekbeli bemutatásától, a koszovói válság tárgyalásától, továbbá a nemzetközi igazgatás jellemzésétől eltekintek. Az ország függetlenségének kikiáltásától kívánom vizsgálni a politikai párbeszédet és a felek lépéseit a megbékélés fényében. Kitérek a Nemzetközi Bíróság tanácsadó véleményére, annak fogadtatására minkét országban, továbbá a párbeszéd 2011-es megkezdésétôl született megállapodásokra. Be kívánom mutatni, hogy miként változtak a tárgyalások vezetői szintjei, így kezdetben szakértői, majd kormányfői, míg végül államfői szintre nem kerültek. Legnagyobb eredménynek a Brüsszeli Megállapodás megkötése számít, amit azonban Koszovó nem alkalmaz. 2017-től konfliktusok sora nehezíti a párbeszédet, így ezek bemutatása is szükséges, ugyanis a tárgyalás felfüggesztéséhez vezettek és a felek közötti kapcsolat elmérgesedését jól jelezte egyrészt a katonai készültségek fokozódása, így biztonságpolitikai vetületet is kapott az ügy. Másrészt pedig Koszovó a vámok egyoldalú megemelésével gazdasági szintre is emelte a feszültséget.
\end{abstract}

Kulcsszavak: Koszovó, Szerbia, dialógus, Európai Unió, Balkán

Abstract: The relations between Serbia and Kosovo are complex. In my study, I will focus on the analysis of events from 2008 to the present, I am not looking of the conflict in the 1980s, a discussion of the Kosovo crisis, and a description of international governance. From the proclamation of the country's independence, I want to examine political dialogue and the steps taken by the parties in the light of reconciliation. I refer to the

${ }^{1}$ Nemzeti Közszolgálati Egyetem, adjunktus. E-mail: ordogh.tibor@uni-nke.hu.

A szerző további munkásságát lásd a Magyar Tudományos Művek Tára oldalán: https://m2.mtmt.hu/gui2/?type=authors\&mode=browse\&sel $=10043535$ 
advisory opinion of the International Court of Justice, its reception in both countries, and the agreements reached since the beginning of the dialogue in 2011. I would like to show how the levels of leadership in the negotiations have changed, so that they were initially experts, then heads of government, and finally heads of state. The biggest achievement is the conclusion of the Brussels Agreement, which, however, is not being applied by Kosovo. From 2017, a series of conflicts will make the dialogue more difficult, so it is necessary to present them, as the escalation of the relationship between the parties and the escalation of the relationship between the parties was well signaled by the increase in military readiness. On the other hand, Kosovo has raised tensions to economic levels by unilaterally raising tariffs.

Keywords: Kosovo, Serbia, dialogue, European Union, Balkan

\section{BEVEZETÉS}

Koszovó és Szerbia kapcsolatrendszere meglehetősen visszás volt az elmúlt negyven évben. Koszovó az egykori Jugoszlávia tartományaként már az 1980-as évektől egyre nagyobb önállóságot követelt magának, azonban az akkori politikai vezetés ezt nem támogatta. Az 1990-es évek háborúi a nemzetközi közösség figyelmét is a térségre irányította, mivel régen nem tapasztalt véres háborúk vették kezdetüket. Tanulmányomban a 2010-tôl napjainkig tartó tíz év fejleményeit fogom elemezni. Terjedelmi korlátok miatt a koszovói háború lezárása utáni időszak nemzetközi igazgatási érája nem kerül bemutatásra, csupán a vitarendezés történetére fókuszálok.

Kutatási kérdésként arra keresem a választ, hogy a felek állami vagy néha személyes érdekei mennyiben írják felül a megbékélés szándékát és milyen ok-okozati összefüggéseket találunk a két terület viszonyában. A tárgyalási keretrendszerben elsôsorban az Európai Unió nyomásgyakorlására térek is, mely soft power eszközeként igyekezett beleszólni a rendezésbe. Munkámban igyekeztem a releváns angol és magyar nyelvü forrásokat felhasználni, ahol speciális információk jelentek meg, ott a napi hírösszefoglalókra támaszkodtam.

Az első fejezetben a kapcsolat normalizálásának körülményeit mutatom be, majd a másodikban a Belgrád-Pristina párbeszéd történéseit vizsgálom meg, ismertetve a főbb eredményeket. A harmadik rész a dialógus elmérgesedését és a tárgyalások megszakítását tárja fel, míg a negyedik fejezetben a 2020 második felében elinduló egyeztetéseket elemzem. 


\section{A KAPCSOLATOK NORMALIZÁLÓDÁSA}

2010. július 22-én látott napvilágot a hágai Nemzetközi Bíróság (angol elnevezés: International Court of Justice, a továbbiakban rövidítve: ICJ) tanácsadó véleménye Koszovó függetlenségével kapcsolatban, amely szerint Koszovó önállósulása nem sértette a nemzetközi jogot. ${ }^{2}$ A hírre reagálva Boris Tadić, Szerbia államfője kijelentette, hogy "Szerbia soha nem fogja elismerni Koszovó függetlenségét."3 Szerbia még 2008-ban fordult az ENSZ-hez, hogy utalja Koszovó függetlenségének kérdését a Nemzetközi Bíróság elé, így október 8-án az ENSZ a szerb kérelemnek helyt adva, továbbította azt az ICJ-nek, hogy vizsgálja meg a koszovói függetlenedés nemzetközi joggal való harmonizációját. ${ }^{4}$

Belgrád az ICJ vélemény után az ENSZ Közgyűléshez fordult, és egy határozatot nyújtott be, amelyben arra kérte az intézményt, hogy utasítsa el Koszovó 2008-as függetlenedését. Az Európai Unió azonban figyelmeztette Belgrádot, hogy ezzel a lépéssel az európai integráció esélyeit veszélyeztetik. ${ }^{5}$ 2010 szeptemberében az EU-s nyomásgyakorlás eredményre vezetett, így Boris Tadić szerb elnök és Catherine Ashton, az EU kül- és biztonságpolitikai főképviselője megállapodást kötött. Ennek értelmében Szerbia - az Európai Unió hatására - módosította az ENSZ Közgyúlés elé benyújtott határozatát, Boris Tadić a megállapodás után kijelentette, hogy "tudomásul veszi a Nemzetközi Bíróság döntését és üdvözli, hogy az EU kész közvetíteni Koszovó és Szerbia között." A párbeszéd megkezdésére azonban egészen 2011 márciusáig kellett várni. A várakozási időszakban a szerb közéletben megjelentek olyan nyilatkozatok, melyek az integráció feláldozását választották volna Koszovóért cserébe.

$2997,2010$.

3 BBC, 2010.

${ }^{4}$ EURACTIV, 2008.

${ }^{5}$ EURACTIV, 2010.

${ }^{6}$ ÖRDÖGH, 2019. 177.o. 


\section{A BELGRÁD - PRISTINA PÁRBESZÉD}

\subsection{Technikai megállapodások és az első brüsszeli egyezmény}

A Belgrád - Pristina párbeszéd 2011 márciusában indult el, ${ }^{7}$ és három témakörre koncentrált: a regionális együttműködésre, a szabad mozgásra, valamint a jogállamiságra. A tárgyalások során technikai kérdések is felmerültek, mint például az energiaellátásnak, a távközlésnek, az országhatárnak, a légiközlekedésnek, a gépjárművek regisztrációjának és a diplomák kölcsönös elismerésének a kérdése. Szerbia nem engedett be légterébe Koszovóba tartó vagy onnan távozó repülőgépeket, a koszovói termékek is tiltólistára kerültek, továbbá nem fogadta el a házassági dokumentumokat és a születési anyakönyvi kivonatokat sem. A felsorolt területek mind a függetlenedés el nem ismeréséből fakadtak, így kompromisszumra kellett jutni bennük A párbeszéd elindulásának céljai között ezen kérdések rendezése is szerepelt. ${ }^{8}$

Eredményeket csak az év végén tudtak elérni, mivel 2011 nyarán, a szerb-koszovói határon erőszakos, halálos áldozatokkal járó összecsapások bontakoztak ki, köszönhetően a Belgrád által Koszovóval szemben bevezetett tilalmaknak. A határátkelőhelynél kialakult konfliktus következtében a tárgyalásokat félbeszakították. ${ }^{9}$ Azonban novemberben folytatták a párbeszédet, amelynek elsô sikere a diplomák kölcsönös elismerésérôl szóló megállapodás volt. ${ }^{10}$ A két fél 2011 decemberében további megállapodást írt alá az Integrált Határ Ellenőrzésről (angol elnevezés: Integrated Border Management, rövidítve: IBM), amelynek értelmében Szerbia és Koszovó közös határállomásokat hozott létre, ezeket az EULEX segítségével múködtették. ${ }^{11}$

Az eredmények következtében Szerbia 2012 márciusában az EU hivatalos tagjelölt államává vált, amelynek közvetlen előzményének tekinthető egy újabb Belgrád és Pristina közötti szerződés aláírása. A február 24-én aláirt megállapodás szerint a továbbiakban Koszovó saját nevén képviseltetheti magát az egyes regionális fórumokon és tárgyalásokon, viszont neve mellé csillag kerül, mely lábjegyzetként azt jelöli, hogy az

\footnotetext{
${ }^{7}$ MEHMETI, 2020. 78.o.

8 SZILVÁGYI, 2012. 4.o.

${ }^{9}$ HUSZKA, 2013a. 6.o.

${ }^{10}$ KITEKINTŐ, 2011.

${ }^{11}$ HuszKA, 2013a. 6.o.
} 
ENSZ BT 1244-es határozata és a hágai Nemzetközi Bíróság véleménye alapján értendő Koszovó jelenléte. „Nemzeti érdekünk, hogy minden akadályt lebontsunk, amely országunk európai uniós tagságának megszerzését gátolja" - nyilatkozta Boris Tadić szerb államfő a szerződésről. ${ }^{12}$ A köztársasági elnök ezzel is bizonyította, hogy Szerbia számára az európai integráció a legfőbb prioritás, és a cél elérése érdekében komoly áldozatokat képes meghozni.

2011 márciusa és 2012 februárja között a fent említett két ügyről szóló megállapodásokon kívül, egyezség született a szabad mozgásról, a népesség-nyilvántartó rendszerről és a diplomák kölcsönös elismeréséről is. $\mathrm{Az}$ eddig elért sikerek ellenére, még számos kihívás várt a két félre. A megoldásra váró ügyek között talán Koszovó nemzetközi színtéren történő képviselete, a párhuzamos intézmények, az energia és telekommunikáció helyzetének rendezése számított a legfontosabbnak. ${ }^{13}$ Koszovó ekkor még nem rendelkezett saját országhívó-számmal, ezért Szerbia 381-es hívószámát kellett használniuk. Ennek oka, hogy kezdetben a Nemzetközi Távközlési Egyesület megtagadta Koszovó kérelmét, hogy kapjanak saját hívószámot, mivel ennek elvileg feltétele az ENSZ-tagság, amit Pristina a mai napig nem szerzett meg. A koszovói ENSZ-tagságról 2013 januárjában Ivica Dačić, akkori szerb kormányfő úgy nyilatkozott egy belgrádi sajtótájékoztatón, hogy hajlandóak tárgyalni erről a kérdésről, azonban cserébe elvárnak valamit Pristinától. ${ }^{14}$ Sokatmondó azonban, hogy a 2013-as nyilatkozat ellenére a mai napig semmilyen előrelépés nem történt ezügyben. Koszovó végül 2016 decemberében megkapta saját országhívó-számát, ami a +383 lett. ${ }^{15}$

A Belgrád - Pristina párbeszéd sikerét bizonyítja, hogy 2012 októberében először ült tárgyalóasztalhoz Ivica Dačić szerb és Hashim Thaçi koszovói kormányfő, az EU kül- és biztonságpolitikai főképviselőjének, Catherine Ashtonnak köszönhetően. A találkozó legfontosabb eredménye, hogy a két fél elkötelezte magát a párbeszéd folytatása és országaik közötti viszony békés rendezése mellett. Szerbiának - a tagjelöltség birtokában ekkor már a csatlakozási tárgyalások megkezdése volt fontos, amiért cserébe folyamatosan engedményeket tett, mind Koszovóval, mind az Európai Unióval szemben. Az EU egyik legnagyobb sikerének tekinthető, hogy

\footnotetext{
12 Milanov, 2012.

${ }^{13}$ HUSZKA, 2013a. 7-8.o.

${ }^{14}$ HVG, 2013.

15 MORINA, 2015.
} 
Szerbia olyan kompromisszumokra is képes és hajlandó volt, amit az EUcsatlakozás lehetősége nélkül valószínúleg soha nem tett volna meg. Az Európai Unió a térség stabilizálásában döntő szerepet vállalt és a csatlakozásért cserébe sok áldozat meghozatalára kényszerítette a két országot. A párbeszéd végső célja a két ország közötti feszültség csökkentése, a helyi lakosok számára jobb életfeltételek biztosítása volt. Az Európai Unió a tagságért cserébe nem várta és talán nem is várhatja el, hogy Szerbia Koszovót önálló, független államnak tekintse, hiszen a tagállamok közül öt ország - Spanyolország, Románia, Görögország, Ciprus és Szlovákia - a mai napig Szerbia részének tekinti a térséget.

A párhuzamos intézmények, azaz Koszovó északi részében múködő szerb intézmények megszüntetéséről szóló 2013. februári brüsszeli tárgyalás nem hozott eredményt. A probléma gyökere az, hogy Koszovó függetlenedése után, az ország északi részében a szerb lakosság csak a szerb közintézmények működését hajlandó elfogadni, míg a pristinai parlament szeretné a saját intézményrendszerét működtetni Koszovó egész területén, így az ország északi térségében is. Az Európai Unió célja, a párhuzamos intézmények megszűntetése Észak-Koszovóban, mivel egyrészt ellenzi a partíciókat az etnikai határok mentén - ez is precedenst teremthet más hasonló helyzetben lévő térségeknek; másrészt az Európai Unió nem tud integrálni olyan országokat, amelyeknek nincsenek konkrétan kijelölve a határvonalai. ${ }^{16}$ 2013. április 19-én végül az EU közvetítésével Szerbia és Koszovó elfogadta az úgynevezett Brüsszeli Megállapodást, melyet mindkét miniszterelnök ellátott kézjegyével. ${ }^{17}$ A kompromisszumokkal teli megállapodás után Ivica Dačić miniszterelnök kijelentette, hogy ez a dokumentum nem jelenti Koszovó függetlenségének elismerését. Pontosan így fogalmaz: "Szerbiának az a célja, hogy megoldja a problémákat Koszovóval, és előre lépjen az Európai Unió felé vezetô úton, de nem ígér olyat, amit nem tud betartani. Szerbia elkötelezett a megállapodásban foglaltak iránt, de nem fogadhat el semmi olyat, amit a dokumentum nem tartalmaz. Szerbia soha nem fogja elismerni Koszovó függetlenségét, sem nyíltan, sem burkoltan."18

A megállapodás Catherine Ashton közvetítésével jött létre, melyről az EU kül- és biztonságpolitikai főképviselője azt mondta: „Szeretnék gratulálni az elmúlt hónapokban tanúsított elkötelezettségükhöz és a bátorságukhoz. Nagyon fontos, hogy az, amit most látunk, az előrelépés a múltból mind-

\footnotetext{
${ }^{16}$ HusZKA, 2013a. 10.

${ }^{17}$ European Council, 2013.

18 PANNONRTV, 2013 a.
} 
kettőjük számára, és egy lépés Európa felé."19 A 15 pontos megállapodást a pristinai parlament április 21-én, a szerb népképviselóház pedig 22-én ratifikálta. $^{20}$ A megállapodás értelmében Szerbiának nem kötelessége elismernie Koszovó függetlenségét, viszont elfogadja, hogy Koszovó egész területe Pristina fennhatósága alá kerül. ${ }^{21}$ Április 22-én, Catherine Ashton konkrét dátum megjelölése nélkül - javaslatot tett arra, hogy Szerbia kezdje meg a csatlakozási, míg Koszovó a társulási megállapodásról szólót tárgyalásokat. Mindez, a két ország közötti kapcsolatok viszonylag sikeresnek mondható rendezésének köszönhető.

Szerb sikernek könyvelhető el, hogy a Koszovó északi területén élő szerb lakosság széles jogköröket kapott, például autonóm hatásköröket a gazdaságfejlesztés, az oktatás, az egészségügy, stb. területén. A rendőrség és a bíróság csak formálisan kerül Pristina alá, mivel szinte maximális önállósággal rendelkezhetnek, amelyben meg kell jelennie a helyi lakosság etnikai összetételének. Az igazságszolgáltatásban is figyelembe kell venni az etnikai arányokat, ennek köszönhetően az észak-koszovói bíróságok tagjait is helyi szerbek alkotják majd. Az autonóm hatáskörök ellenére a koszovói jogszabályok léptek érvénybe a területen, melyek az itt élő szerbek heves ellenérzését váltották ki. ${ }^{22}$ A dokumentum 13-as pontja szerint felgyorsítják a tárgyalásokat az energetikai rendszerről és a távközlésről, júniusra be is fejezik azt. Az erről szóló megállapodás szintén az egyik előfeltétele volt az integrációs tárgyalások megkezdésének. Végül nem júniusban, hanem szeptemberben sikerült a két félnek egyezségre jutnia a kérdésben, melynek eredménye az energetikai és távközlési rendszer zavartalan múködése Koszovó területén. ${ }^{23}$ Megállapodtak arról is, hogy a két fél nem akadályozza a másikat, vagy nem támogat olyan felet, aki gátolja ôket, hogy haladást érjenek el az európai integráció útján. ${ }^{24}$ Az EU felé vezető összes közlekedési útvonal Szerbián keresztül vezet, Szerbia viszont eddig tiltotta a koszovói áruk szerb területre történő behozatalát, ami mind az export-import, mind pedig a külföldi tóke beáramlása által remélt gazdasági fejlődést is meghozhatja Koszovó számára.

A megállapodás tétje a szerb integráció folytatása, azaz a csatlakozási tárgyalások megkezdése volt, az EU ugyanis a hágai Nemzetközi Törvényszékkel

\footnotetext{
${ }^{19}$ Mattson, 2013.

${ }^{20}$ B92, 2013a.

${ }^{21}$ HUSZKA, 2013b. 3.o.

${ }^{22}$ HuSZKA, 2013b. 3-6.o.

${ }^{23}$ PANNONRTV, 2013b.

${ }^{24}$ B92, 2013b.
} 
való együttmúködés után a szerb-koszovói viszony normalizálását szabta feltételül. Ennek a szerződésnek az aláirása egy fontos lépés volt, de nem a párbeszéd végét jelentette, hiszen még további technikai kérdések is megoldásra vártak, ráadásul a brüsszeli megállapodásban foglaltak egészében történő megvalósulása is időbe telik.

A szerb csatlakozással kapcsolatban Németország kezdeményezte, hogy még a csatlakozási tárgyalások előtt, 2013 decemberében ellenőrizzék a Belgrád - Pristina megállapodások hatékony végrehajtását, amennyiben a vizsgálat pozitív eredménnyel zárul, már semmilyen akadálya nem lesz a csatlakozási folyamatnak. ${ }^{25}$ A vizsgálat után Brüsszelben tartott beszédében Catherine Ashton kijelentette, hogy Szerbia teljesítette az Európai Unió által kiszabott összes feltételt, ennek köszönhetően hamarosan megkezdődhetnek a tárgyalások. ${ }^{26}$ December 17-én, Štefan Füle, az Európai Unió akkori bővítési biztosa Twitter-bejegyzésében az „Első Kormányközi Konferencia”, ezáltal a csatlakozási tárgyalások kezdetének tervezett napját is közzétette. ${ }^{27}$ Ivica Dačić, szerb miniszterelnök a brüsszeli sajtótájékoztatón felvázolta Szerbia tervezett lépéseit a jövőre nézve, mely szerint 2018-ra minden EU-s követelményt teljesítenek, és 2020-ra teljes jogú tag kíván lenni. ${ }^{28}$

2014. január 21-én megkezdődtek Szerbia európai uniós csatlakozási tárgyalásai. Ennek legfontosabb előzménye, a Belgrád - Pristina párbeszéd, amit Koszovó sikernek könyvelhet el, mert ezáltal ôk is közelebb kerültek az Európai Unióhoz, és 2013. október 28-án a Stabilizációs és Társulási Megállapodásról szóló tárgyalásokat is megkezdhették. ${ }^{29}$ A korábban már említett gazdasági fejlődés útján is elindulhatott Koszovó, a várt külföldi befektetők és tőke beáramlásának köszönhetően, hiszen a megállapodásból fakadóan ekkor még Szerbia nem törekedett Koszovó nemzetközi elszigetelésére. Győztesnek érezhette magát Szerbia is, mivel a viszonyok normalizálása miatt folytatódhatott az európai integráció, sőt, a csatlakozási tárgyalások is megkezdődtek. A tárgyalások megkezdése kompenzálhatta azt a tényt, hogy Szerbia elveszítette történelmileg igen jelentős tartományát. Végül pedig győztesnek érezheti magát az Európai Unió is, hiszen tárgyalóasztalhoz tudta ültetni a két felet, és viszonylag rövid idő alatt - két év - olyan megállapodást sikerült kidolgoznia és elfogadtatnia a két

\footnotetext{
${ }^{25}$ NAGY, 2013.

${ }^{26} \mathrm{~B} 92,2013 \mathrm{c}$.

${ }^{27}$ FÜLE, 2013.

28 AP, 2014.

29 2013/2881(RSP) EP ÁLLÁSFOGLALÁS.
} 
országgal, amely a viszonyaikat normalizálta és a békés egymás mellett élést segítette elő. Az EU kihasználta azt a fegyvertényt, hogy a csatlakozás - és az ezt követő anyagi támogatások - iránt érzett vágyódás alkalmas motivációt jelentett Szerbia számára, hogy részt vegyen egy Koszovóval folytatott párbeszédben, majd kompromisszumokat kössön bizonyos kérdésekben.

\subsection{A második brüsszeli egyezmény}

A csatlakozási konferencia megnyitása után újfent a belpolitikai csatározások kerültek középpontba. Tomislav Nikolić, akkori szerb államfő pár nappal a konferencia megnyitása előtt egy televíziós interjúban úgy fogalmazott, hogy Szerbiának jobb kormánya is lehetne, emiatt előrehozott választások kiírását preferálja. ${ }^{30}$ A cél egy erős kormányzó párt, mely a választók akaratát tükrözi. Az előrehozott választások győztesével a csatlakozási tárgyalások megkezdése is könnyebbnek bizonyulna. Az előrehozott választásokat 2014. március 16-ára tűzte ki az államfő, amelyet az Aleksandar Vučić által vezetett Szerb Haladó Párt (szerb kifejezéssel: Srpska Napredna Stranka, rövidítve: SNS) nyert meg, a szavazatok 48 százalékának megszerzésével. Vučić több alkalommal is felszólalt az európai integráció mellett, valamint azért, hogy Szerbia számára továbbra is az elsődleges prioritások között szerepel az uniós csatlakozás befejezése. ${ }^{31}$ Továbbá fontos kiemelni, hogy az integráció elkezdése óta most először nem kerültek be a parlamentbe euroszkeptikusok. ${ }^{32}$ Így a csatlakozási tárgyalások folytatása nem került veszélybe. A külügyminiszter a korábbi miniszterelnök, Ivica Dačić lett, aki a csatlakozás végét a korábbiakhoz képest reálisabban kezelte, a korábbi 2020-as időpont helyett 2024-et említett egyik beszédében, hozzátéve, hogy: „Szerbia az európai család tagja akar lenni." 33

A csatlakozási tárgyalások során az uniós országok és a tagjelölt ország kormányai közötti kormányközi konferenciákon kezdetét veszi az uniós joganyag és a tagjelölt országok jogharmonizációja. A joganyagokat 35 fejezetbe sorolják be, melyeket sorra nyitnak meg és külön vizsgálódás

\footnotetext{
30 BALKANINSIGHT, 2014a.

${ }^{31}$ NAGY, 2014.

32 BALKANINSIGHT, 2014b.

${ }^{33}$ KITEKINTŐ, 2014a.
} 
tárgyát képezik. ${ }^{34} \mathrm{Az}$ első fejezetek megnyitására viszonylag sokat kellett várni, amit a Belgrád és Pristina közötti kapcsolat rendezésének elhúzódásával indokoltak az EU képviselői. ${ }^{35}$ 2015. december 14-én végül két fejezetet is megnyitottak, a Pénzügyi ellenőrzésről szólót, és az Egyéb ügyeket, melybe beletartozik Szerbia és Koszovó kapcsolatainak békés úton történő rendezése. ${ }^{36}$ Aleksandar Vučić még 2014-ben úgy nyilatkozott, hogy minél előbb szeretnék elkezdeni a fejezetekrôl szóló tárgyalásokat, továbbá más országokkal ellentétben, ő a legnehezebb fejezetek megnyitását preferálta. ${ }^{37}$ Az Európai Unió meg akarta „lovagolni” a Belgrád - Pristina párbeszéd kezdeti sikereit, a csatlakozási tárgyalások hivatalos megkezdését és erre alapozva további engedmények elérésére akarta sarkallni a szerb kormányzatot Koszovót illetően. Hiába azonban a miniszterelnök és az egész szerb kormányzat EU-integráció iránti elköteleződése, az EU ezen törekvése kudarcba fulladt.

Koszovóban belpolitikai válság vette kezdetét 2014-ben, több mint fél évig kormány nélkül maradtak, ami a Belgráddal való párbeszédet is akadályozta. A kormánynélküliség hosszú hónapjai után végül Hashim Thaçi és az ellenzéki Isa Mustafa megállapodtak egymással, melynek értelmében Mustafa lett Koszovó új miniszterelnöke, Thaçi pedig a külügyminiszter és a miniszterelnök-helyettes is egyben. ${ }^{38}$ A párbeszéd, hosszabb szünet után 2015 februárjában folytatódott, Aleksandar Vučić szerb és Isa Mustafa koszovói kormányfő között. A tárgyalást Federica Mogherini, az Európai Unió új kül- és biztonságpolitikai főképviselője vezette. ${ }^{39}$

A párbeszéd újabb sikere 2015. augusztus 25-én következett be, amikor Brüsszelben ismét egy történelminek tekinthető megállapodást kötöttek a felek. Négy témában sikerült egyezségre jutniuk: az energetika, a mitrovicai híd használata, a távközlés és a szerb többségű helyi önkormányzatok szövetségéről szóló szabályozás terén. Hashim Thaçi értékelése szerint „Szerbia bizonyos értelemben elismert minket független államnak." ${ }^{40}$ A korábban említett országhívó-szám problémája ekkor oldódott meg, de ami a legfontosabb, hogy ebben az esetben a megállapodást nem Belgrád és

\footnotetext{
${ }^{34}$ EUR-LEX, 2020.

35 EUROPA.RS, 2015.

${ }^{36}$ European Council, 2015.

${ }^{37}$ KITEKINTŐ, 2014b.

38 BAJTAY, 2014.

${ }^{39}$ KITEKINTŐ, 2015.

${ }^{40}$ BBC, 2015.
} 
Pristina kötötte egymással, hanem Szerbia és Koszovó, mint két szuverén állam. Thaçi kijelentése, ha túlzó is, de mindenféleképpen előrelépésként lehet értékelni. A koszovói lakosság és az ellenzék azonban a megállapodás után heves tiltakozásba kezdett, azt követelve, hogy Mustafa kormányfő vonja vissza aláírását. A koszovói alkotmánybíróság pedig novemberben ideiglenesen felfüggesztette a megállapodást. ${ }^{41}$ A második brüsszeli megállapodás tehát ahelyett, hogy elősegítette volna a megbékélést, súlyos következményeket vont maga után. 2015 decemberében az alkotmánybíróság kijelentette, hogy a brüsszeli megállapodás összeegyeztethető a koszovói alaptörvénnyel - azzal a megkötéssel, hogy az intézmény végrehajtó jogosítványokkal nem rendelkezhet -, így az újra hatályba lépett, és ezzel megalakulhatott volna a kisebbségi szerb önkormányzatok közössége. ${ }^{42} \mathrm{Az}$ alkotmánybíróság határozatától függetlenül a probléma nem oldódott meg, mivel a szerb fél számára pontosan az önálló és a központi kormányzattól nagymértékben független szerb önkormányzatiságban látja a megoldást. A végrehajtási funkciók vitája nyomán a brüsszeli megállapodást a koszovói fél a gyakorlatban nem hajtja végre, így Szerbia elvárása nem teljesült, ami a párbeszéd folytatásának záloga volt.

\section{A KAPCSOLAT ELMÉRGESEDÉSE}

2016 a stagnálás évének számított a vitatott alkotmánybírósági határozat nyomán. A két fél közötti viszony 2017 januárjában mérgesedett el igazán, amikor Szerbia egy vonatot indított el az Észak-Koszovóban lévő Kosovska Mitrovicába, amelynek oldalán a szerbiai zászló, ortodox ikonképek és a „Koszovó Szerbia (része)” felirat szerepelt 21 nyelven. ${ }^{43}$ Aleksandar Vučić végül még Szerbia területén megállíttatta a vonatot, attól tartva, hogy a koszovói albánok aláaknázzák a vasúti síneket. Thaçi, akit 2016-ban Koszovó államfőjének választottak, provokációnak minősítette az esetet, mellyel ürügyet akartak szolgáltatni arra, hogy Belgrád katonai erővel beavatkozzon Észak-Koszovóban, és így visszacsatolja Szerbia egykori tartományát. „Ez a krími modell”, mondta Thaçi. A szerb vezetés válaszul kijelentette, hogy nem ők, hanem a koszovóiak akarnak háborút, és csak Vučićnak köszönhető, hogy nem történtek véres összecsapások az eset

41 INDEX, 2015.

42 ECMIK, 2016. 1.o.

${ }^{43}$ ECMIK, 2018. 5-6.o. 
után. ${ }^{44}$ Az Európai Unió érzékelte, hogy a helyzet fokozatosan romlik, így Brüsszelbe hívták szerb részről Tomislav Nikolić államföt és Aleksandar Vučić kormányfőt, valamint koszovói oldalról Hashim Thaçi államföt és Isa Mustafa kormányfőt. Federica Mogherini, a találkozó vezetője kijelentette, hogy bizakodásra adnak okot a megbeszélésen elhangzottak. A tárgyalás célja, hogy folytassák a 2013-ban elkezdett párbeszédet. ${ }^{45}$

A kapcsolatok normalizálása azonban elmaradt, mivel egy újabb közjáték következett. Ramush Haradinaj letartóztatása, majd kormányfővé válása. Szerbia még 2006-ban adott ki nemzetközi elfogatóparancsot Ramush Haradinaj, a Koszovó Jövőjéért Szövetség párt vezetője, a Koszovói Felszabadítási Hadsereg egykori gerillaparancsnoka ellen. 2015ben Szlovéniában le is tartóztatták, de nem adták ki Szerbia számára. Hasonlóan zajlott le a 2017-es őrizetbe vétel is, amikor Franciaországban került efféle helyzetbe. Haradinaj ellen háborús bűnök miatt adott ki elfogatóparancsot Szerbia. Haradinaj azonban két ízben, 2008-ban és 2012ben már állt a hágai Nemzetközi Törvényszék előtt, ahol mindkét alkalommal felmentették a háborús bűnök vádja alól (2019-ben ismét meghallgatták az új speciális bíróságon, de vádat nem emeltek ellene). Szerbia 1998-ban és 1999-ben elkövetett háborús bűnök és civilek gyilkolásának vádjával 108 bűnvádi feljelentést tett az egykori gerillaparancsnok ellen. ${ }^{46}$ Végül Franciaország sem adta ki Szerbiának, hanem szabadon bocsátották. A helyzet pikantériáját később az adta, hogy a 2017ben a koszovói előrehozott parlamenti választások eredményeként Haradinaj lett az ország miniszterelnöke. A Belgrád-Pristina közötti párbeszéd hanyatlásában ez is közrejátszott. A szerbiai vezetésben is változás történt 2017-nen, Aleksandar Vučićot államfővé választották.

2018-ban Szerbia vezetése érzékelve a nyomást békülékenyebb hangnemre váltott. Vučić szerb elnök februárban kijelentette, hogy új javaslatot kíván előterjeszteni. Sokan úgy vélték, hogy ezzel megszülethet egy olyan dokumentum, amely rendezi a kapcsolatokat és biztosítani tudja Koszovó részvételét a nemzetközi szervezetekben, de az egykori tartomány önállóságának elismerését nem kell megtenniük. ${ }^{47}$ Végül ez sem valósult meg. Az újabb remény 2018 nyarán pár hét erejéig ismét megjelent. Thaçi koszovói államfő a határkorrekció ötletét vetette fel, melytől Vučić szerb

\footnotetext{
44 BYTYCI, 2017.

45 KITEKINTŐ, 2017.

46 EWB, 2017.

47 EMINI - STAKIC, 2018. 7.o.
} 
elnök sem zárkózott el. ${ }^{48}$ Sajnos sok részlet ezzel kapcsolatban sem látott napvilágot, valószínúleg a korábban javasolt megoldás jött volna létre (észak-koszovi szerb lakta területek cseréje a Preševo-völgyért cserébe). Bár úgy tûnt, hogy a felek meg tudnak egyezni, az EU részéről aggodalom jelent meg, hogy ez csak egy speciális megoldás legyen, ne teremtsen precedenst, míg az Amerikai Egyesült Államok támogatásáról biztosította a feleket.

A viszony rendezését a politikai villongások sem könnyítették meg. 2018. szeptember 29-én Hashim Thaçi államfő ellátogatott a Gazivodatóhoz, melyre mindkét állam igényt tart. A köztársasági elnök védelmét a ROSU különleges egység látja el, így az említett szervezet hatvan fegyverese is vele tartott. Ma már az sejthető, hogy inkább Thaçi testőreiről volt szó és nem különleges katonákról. A szerbek szerint ez a terület feletti szimbolikus harcot jelentette és rosszhiszemú katonai akcióról beszéltek. Aleksandar Vučić köztársasági elnök parancsára a szerb hadsereget a legmagasabb szintű harci készültségbe helyezték. A parancsot továbbították a vezérkarba, mert az indoklás szerint az albán különleges egységek megtámadták a Koszovó északi részén élő szerbeket. A készültséget október 4-én vonták vissza. ${ }^{49}$ A második afférra 2019. május 28 -án került sor, amikor a ROSU tagjai kora reggel behatoltak mind a négy koszovói szerb község területére és letartóztatásokat hajtottak végre a szervezett bűnözés elleni fellépés részeként. ${ }^{50}$ Aleksandar Vučić ekkor is elrendelte a szerb katonaság teljes harci készültségét. Hozzátartozik az igazsághoz, hogy a koszovóiak bűnüldözési műveletéről Szerbia és a KFOR is tájékoztatást kapott Pristinától.

A felek közötti vita egyik csúcspontját az jelentette, amikor 2018. november 21-én a koszovói kormány Haradinaj kormányfő javaslatára 100\%-os vámot vetett ki a Szerbiából és Bosznia-Hercegovinából származó termékekre. ${ }^{51}$ A koszovói kormányzat mindezt azzal indokolta, hogy a tőlük származó bevételeket a két ország arra használja fel, hogy ellehetetlenítsék Koszovó nemzetközi elismertségét. Szerbia vezetői ekkorra valóban azt a diplomáciai célt fogalmazták meg, hogy szeretnék, ha Koszovó önállóságát elismerő államok száma csökkenne és ennek érdekében Oroszországgal együtt diplomáciai offenzívába kezdtek. A közvetlen kiváltó ok pedig az volt, amikor a szerbek megakadályozták, hogy Koszovó az Interpol tagjává váljon.

\footnotetext{
48 EWB, 2018.

49 VAJMA, 2018.

${ }^{50}$ FARKAS, 2019.

51 BPRG, 2019. 13.o.
} 
Miután kiszivárgott hírek szerint Haradinaj koszovói kormányfő ellen ismét vádat kívántak emelni a koszovói háborúban elkövetett bűnök gyanúja miatt, benyújtotta lemondását. A koszovói belpolitikai instabilitás nyomán 2019-ben előrehozott választások kiírása mellett döntöttek. A kampány érdekes választási szövetségeket hozott létre, mivel egyik oldalon megjelent a „béke” koalíciója, míg a másikat a „háború” szövetsége jelentette, utalva a koszovói konfliktusban betöltött politikusok szerepére. A választás felfokozott belpolitikai hangulata nyomán az Önrendelkezés (Vetëvendosje), a harmadik erô került ki győzztesként, de koalíciós partnerre szorult. A tárgyalások eredményeként 2020 február elején Albin Kurti, a Vetëvendosje elnöke megszerezte magának a kormányfői széket, ${ }^{52}$ viszont instabil kormánytöbbséget tudott maga mögött. Kurtiék mindig is éles hangot ütöttek meg a Belgráddal folytatott tárgyalásokat kritizálva, így félő volt, hogy a viszony továbbra is rossz marad. A kormány a koszovói belső problémák (korrupció, szervezett bűnözés, munkanélküliség, stb.) csökkentésére koncentrált volna a külpolitikai célkitűzésekkel szemben, a párbeszédet pedig a koszovói albánság és az észak-koszovói szerbség között részesítette volna előnyben, mintsem Koszovó és Szerbia között. A közös kormányzás egyáltalán nem bizonyult sikeresnek, mivel március végén már kisebb koalíciós partnere, a Koszovói Demokratikus Liga (Lidhja Demokratike e Kosovës - LDK) bizalmatlansági indítvány terjesztett be a parlamentbe, amellyel meg is bukott a kormány. Ezután nem egy újabb rendkívüli választás kiírására került sor, hanem az $\mathrm{LDK}$ új partnereket keresve alakította ki az új kormányzat összetételét.

\section{REMÉNY A MEGEGYEZÉSRE}

A viszony ismételt normalizálására csak akkor kerülhetett sor, amikor Koszovó visszavonta a büntetôvámokat, melyet az új koszovói kormányfő, Avdullah Hoti 2020. június 6-án megtett. ${ }^{53}$ Ezután Miroslav Lajčák, a Belgrád és Pristina közötti párbeszéd kezeléséért felelős uniós megbízott arról számolt be, hogy a tárgyalások júliusban fognak folytatódni a felek között. ${ }^{54}$ A rendezésben az EU mellett az Amerikai Egyesült Államok is aktivizálta magát, amelynek szintén kinevezésre került egy különbmegbízottja a párbeszéd folytatásáért, Richard Grenell szemé-

\footnotetext{
${ }^{52}$ EWB, 2019a.

${ }^{53}$ EWB, 2020a.

54 SZABAD MAGYAR SZÓ, 2020.
} 
lyében. ${ }^{55}$ A tervek szerint június 27-én Washingtonban tartották volna meg az újabb fordulóját a közeledésnek, azonban nem sokkal korábban vádat emeltek Hashim Thaçi koszovói államfövel szemben a háborúban vélt cselekményeiért. Ezzel meghiúsult a tárgyalás lehetôsége, mivel a koszovói köztársasági elnök lemondta részvételét az összejövetelen. Később a felek amerikai helyett uniós közvetítéssel július 10-én tárgyaltak videókonferencián, ahol a koszovói fél részéről az államfő helyett Avdullah Hoti vett részt, amit egy újabb, ezúttal személyes találkozó követett volna július 14-én Brüsszelben, de ezt végül elhalasztották.

$\mathrm{Az}$ amerikai diplomáciának szeptember 4-ére sikerült megszerveznie a párbeszéd újabb fordulóját. A washingtoni megállapodás ${ }^{56}$ többnyire gazdasági területre vonatkozó együttmúködéseket jelent, de megegyeztek abban is, hogy egy évre Szerbia felfüggeszti a Koszovó elismerésének visszavonására indított kampányát, cserébe az egykori tartomány nem tesz lépéseket a nemzetközi intézményekbe történő felvételekkel kapcsolatban. A szerződés részét képezi a vasúthálózat fejlesztése, az utasok átvilágításának megosztása, a Gazivoda tavon lévő közös erőmú hasznosításának lehetősége, továbbá Koszovó „mini-Schengen”-hez történő csatlakozása. ${ }^{57}$ Szeptember 7-én Brüsszelben is tartottak egy fordulót, ahol az EU kül- és biztonságpolitikai főképviselője (Josep Borell), valamint a tárgyalásokért felelős megbízott (Miroslav Lajčák) is részt vett. A találkozót sikeresnek könyvelték el, mivel „teljes előrelépés történt” a gazdasági együttműködés, az eltűnt személyek és a lakóhelyüket elhagyni kényszerült személyek témájában. ${ }^{58}$

\section{KONKLÚZIÓ}

Az elmúlt tíz év Szerbia és Koszovó viszonyában hullámvasútra emlékeztető folyamatot jelentett. A valódi politikai normalizálódás 2010ben, a Nemzetközi Bíróság által kiadott tanácsadó véleménnyel vette kezdetét és az Európai Unió volt az a partner, aki egy asztalhoz ültette a két ország vezetését.

Véleményem szerint az alábbi következtetéseket tudjuk levonni az elmúlt tíz év tanulságából:

\footnotetext{
${ }^{55}$ EWB, 2019b.

${ }^{56}$ EWB, 2020 b.

${ }^{57}$ BPRG, 2020. 9.

${ }^{58}$ EWB, 2020c.
} 
1) Az Európai Unió megpróbálta soft power erejét kihasználni a felek közötti megbékélés elősegítésére, azonban ez nem vezetett teljeskörü eredményhez, így a közösség nem tudott maximális sikert elérni a külpolitikai céljaiban. Az EU-tagsággal és a társult tagsággal való kecsegtetés ideig-óráig megfelelő lehetőséget adott, viszont az EU sem ragaszkodott maximálisan a viszony rendezéséhez és politikai kompromisszumok árán hagyta, hogy a nemzetközi rendezettség elmaradjon.

2) A nemzetközi akarattól függetlenül az egyes országok politikai vezetése az erôs nyomásgyakorlás ellenére is kitartanak álláspontjuk mellett, amelyet nagymértékben befolyásol a hatalmon lévők akarata és taktikai megfontolásai. Láthattuk, hogy a koszovói belpolitika mennyire instabil, a konfrontatív politikusok (Haradinaj, Kurti) elzárkóztak a rendezéstől, míg Vučić személyében egy békülékeny politikust ismerhettünk meg.

3) A vitás kérdések rendezése a technikai és gazdasági kérdésekben lehet sikeres. A létrejött megállapodások életbe lépése olyan területekre vonatkozott, melyek a felek számára kevésbé érzékeny területeket jelentettek és minkét ország vezetése nyert ezáltal, továbbá a hazai közvélemény számára is könnyebben kommunikálható engedményeket jelentett. Mindezt jelentette a kezdeti technikai megállapodások megkötése, vagy akár a 2020 őszi washingtoni gazdasági szerződés. Mindezekkel a felek nyernek a valóságban; a politikai viták (például Koszovó nemzetközi intézményekbe történő integrálódása) „,befagyasztásra” kerültek.

4) Azokban a kényes témákban, melyek nagyarányú politikai feszültséggel terheltek nem sikerült kompromisszumot kötni, vagy legalábbis a gyakorlatban ezeket nem sikerült végrehajtani. Az elmúlt években két fontos elvárás nem teljesült. Egyrészt Koszovó adós az északi szerb községek szövetségének létrehozásával, de erre nem is halljuk hogy akár az EU, akár az USA felszólítaná őket. Másrészt az a nemzetközi dokumentum is hiányzik, ami végleg rendezné a két terület vitáját, ehhez azonban minden részes fél aktív közremúködésére szükség van.

Bizakodásra ad okot, hogy mindkét ország vezetése hajlandó leülni egy asztalhoz és ha szimbolikusan is, de egy-egy részterületen előrelépésekről tudunk beszámolni. Talán a szerb-koszovói konfliktust is a kislépések politikájával sikerül majd megoldani, bár az idő sürget mindenkit, ha 2025-re Szerbia teljes jogú tagságát tényleg komolyan gondolták az Európai Unióban. 


\section{FELHASZNÁLT IRODALOM}

2013/2881(RSP) EP ÁLLÁSFOGLALÁs. Az Európai Parlament 2014. január 16-i állásfoglalása Koszovó európai integrációs folyamatáról - 3. pont. 2014.01.16.

Elérhető: http://www.europarl.europa.eu/sides/getDoc.do?pubRef=L/EP//TEXT+TA+P7-TA-2014-0040+0+DOC+XML+V0//HU (Letöltve: 2020.01.27.)

AP (2014): Serbia looking for EU membership by 2020. AP, 2014.01.21. Elérhetô: https://apnews.com/080649b1c1eb47438a1818a738a51002 (Letöltve: 2020.01.27.)

B92 (2013a): Government adopts Brussels agreement. B92, 2013.04.22. Elérhető: https://www.b92.net/eng/comments.php?nav id=85829 (Letöltve: 2020.01.27.)

B92 (2013b): Unofficial text of proposed Kosovo agreement. B92, 2013.04.19.

Elérhetô: https://www.b92.net/eng/news/politics.php?yyyy=2013\&mm $=04 \& d d=19 \&$ nav id=85799 (Letöltve: 2020.01.27.)

B92 (2013c): Ashton: Serbia meets all requirements. B92, 2013.12.17. Elérhetô: http:/ / www.b92.net/eng/news/politics.php?yyyy=2013\&mm $=12 \& \mathrm{dd}=17 \&$ nav id=88677 (Letöltve: 2020.01 .27 .)

BBC (2010): Serbia rejects UN legal ruling on Kosovo's secession. BBC, 2010.07.23. Elérhető: http://www.bbc.co.uk/news/world-europe10734502 (Letöltve: 2020.01.27.)

BBC (2015): Kosovo and Serbia sign ,landmark' agreement. BBC News, 2015.08.26. Elérhető: http://www.bbc.com/news/world-europe34059497 (Letöltve: 2020.01.27.)

BAjTAY MÁTÉ (2014): Megszavazták a héten az új koszovói kormányt. Kitekintő, 2014.12.13.

Elérhető: http://kitekinto.hu/europa/2014/12/13/megszavaztak a het en az uj koszovoi kormanyt (Letöltve: 2020.01.27.)

BalKanINSIGHt (2014a): President: Serbia Can Have Better Government. Balkan Insight, 2014.01.03. Elérhető: http://www.balkaninsight.com/en/article/president-serbia-can-havebetter-government (Letöltve: 2020.01.27.)

BalkanInsight (2014b): Serbia Press Review - March 20, 2014. Balkan Insight, 2014.03.20. 
Elérhető: http:/ /www.balkaninsight.com/en/article/serbia-pressreview-march-20-2014 (Letöltve: 2020.01.27.)

BPRG (2019): Kosovo 2020: A Complex Agenda for the New Government. Balkans Policy Research Group, 2019.12.17. Elérhető: https://balkansgroup.org/en/kosovo-2020-a-complex-agenda-for-thenew-government-2/ (Letöltve: 2020.11.03.)

BPRG (2020): Kosovo-Serbia Dialogue: Path to the Agreement. Balkans Policy Research Group, 2020.10.02. Elérhetô: https://balkansgroup.org/wpcontent/uploads/2020/10/Kosovo-Serbia-Dialogue-Path-to-theAgreement-02.10.2020-.pdf (Letöltve: 2020.11.03.)

BYTYCI, FATOS (2017): Serbia wants to annex part of Kosovo using „Crimea model“: president. Reuters, 2017.01.16. Elérhető: http://www.reuters.com/article/us-serbia-kosovo-presidentidUSKBN15022Y (Letöltve: 2020.01.27.)

ECMIK (2016): The Constitutional Court's decision on the Association/Community of Serb Mayority Municipalities. Kosovo Communities Issues Monitor, 2016.01.28. Elérhető: https://www.ecmikosovo.org/uploads/CommunityAssociation-Agreement-23-Decmber-ENG1.pdf (Letöltve: 2020.11.03.) ECMIK (2018): Update on the Process of Association of Serb-Majority Municipalities. Kosovo Communities Issues Monitor, 2018.04. Elérhető: https://www.ecmikosovo.org/uploads/Policy $\% 20$ Brief $\% 20 \mathrm{As}$ sociation $\% 20 \mathrm{of} \% 20$ Serb $\% 20$ Majority $\% 20$ Municipalities $\% 20 \mathrm{ENG} \% 20 \mathrm{P}$ DF.pdf (Letöltve: 2020.11.03.)

EMINI, DONIKA - STAKIC, IsIDORA (2018): Belgrade and Pristina: lost in normalisation? Brief Issues, European Union Institute for Security Studies, 2018/5. Elérhető: https://www.iss.europa.eu/sites/default/files/EUISSFiles/Bri ef $\% 205 \% 20$ Belgrade $\% 20$ and $\% 20$ Pristina.pdf (Letöltve: 2020.11 .03 .)

EUR-LEX (2020): Csatlakozás az EU-hoz - a csatlakozás folyamata. Európai Unió, 2012.10.26. Elérhető: http://eur-lex.europa.eu/legalcontent/HU/TXT/?uri=LEGISSUM:114536 (Letöltve: 2020.01.27.)

EURACTIV (2008): Serbia hails diplomatic triumph over Kosovo. EurActiv, 2008.10.09. Elérhető: http://www.euractiv.com/enlargement/serbiahails-diplomatic-triumph-kosovo/article-176206 (Letöltve: 2020.01.27.) 
EURACTIV (2010): EU tells Serbia to give up Kosovo ,last battle'. EurActiv, 2010.08.31. Elérhetô: http://www.euractiv.com/enlargement/eu-tellsserbia-give-kosovo-last-battle-news-497310 (Letöltve: 2020.01.27.)

EUROPA.RS (2015): Mogherini in Belgrade: Firmly on the EU Path. Europa.rs, 2015.03.28. Elérhető: http://europa.rs/mogherini-inbelgrade-firmly-on-the-eu-path/?lang=en (Letöltve: 2020.01.27.)

European Council (2013): The President: Statement by the President of the European Council Herman Van Rompuy, on the occasion of the agreement within the facilitated dialogue on the normalisation of relations between Serbia and Kosovo. 2013.04.19. Elérhető: http://europa.eu/rapid/press-release PRES-13-159 en.htm (Letöltve: 2020.01.27.)

European Council (2015), Accession conference with Serbia: First two chapters opened. Council of the EU, 2015.12.14. Elérhetô: http://www.consilium.europa.eu/en/press/press-releases/2015/12/14accession-conference-serbia/ (Letöltve: 2020.01.27.)

EWB (2017): French court rejects Serbian extradition request for Haradinaj. European Western Balkans, 2017.04.27. Elérhető: https://europeanwesternbalkans.com/2017/04/27/frenchcourt-rejects-serbian-extradition-request-for-haradinaj/ 2020.11.03.)

EWB (2018): Alpbach 2018 Forum: Thaçi and Vučić discuss border correction with the panel. European Western Balkans, 2018.08.25. Elérhetô: https://europeanwesternbalkans.com/2018/08/25/alpbach2018-forum-thaci-vucic-discuss-border-correction-panel/ (Letöltve: 2020.11.03.)

EWB (2019a): Kosovo election: Incumbents defeated, dialogue with Belgrade to be resumed? European Western Balkans, 2019.10.07. Elérhető: https://europeanwesternbalkans.com/2019/10/07/kosovoelection-incumbents-defeated-dialogue-with-belgrade-to-be-resumed/ (Letöltve: 2020.11.03.)

EWB (2019b): Richard Grenell named US Special Envoy for BelgradePristina dialogue. European Western Balkans, 2019.10.04. Elérhető: https://europeanwesternbalkans.com/2019/10/04/richard-grenellnamed-us-special-envoy-for-belgrade-pristina-dialogue/ (Letöltve: 2020.11.03.)

EWB (2020a): Kosovo lifts tariffs on goods from Serbia and $\mathrm{BiH}$, reciprocity measures introduced towards Serbia. European Western 
Balkans,

2020.04.01.

Elérhető: https://europeanwesternbalkans.com/2020/04/01/kosovolifts-tariffs-on-goods-from-serbia-and-bih-reciprocity-measuresintroduced-towards-serbia/ (Letöltve: 2020.11.03.)

EWB (2020b): Documents signed at the White House cover wider scope than expected- European Western Balkans, 2020.09.04. Elérhetô: https://europeanwesternbalkans.com/2020/09/07/thefourth-meeting-at-the-expert-level-was-held-between-belgrade-andpristina/ (Letöltve: 2020.11.03.)

EWB (2020c): The fourth meeting at the expert level was held between Belgrade and Pristina. European Western Balkans, 2020.09.07. Elérhetô: https://europeanwesternbalkans.com/2020/09/07/thefourth-meeting-at-the-expert-level-was-held-between-belgrade-andpristina/ (Letöltve: 2020.11.03.)

FARKAS GYÖRGY (2019): Teljes harckészültségben Szerbia. 24.hu, 2019.05.28. Elérhető: https://24.hu/kulfold/2019/05/28/teljesharckeszultsegben-szerbia/ (Letöltve: 2020.01.28.)

FÜLE, ŠTEFAN (2013): “\#GAC on \#Serbia: acknowledges reform and normalization efforts, First Inter-Governmental Conference planned for $21 \quad$ Janaury." Twitter, 2013.12.17. Elérhető: https://twitter.com/StefanFuleEU/status/4130055327701073 $\underline{92}$ (Letöltve: 2020.01.27.)

HuszKa BEÁtA (2013a): The EU-Serbia-Kosovo Triangle: an Enduring Impasse. MKI-Tanulmányok T-2013/6. Elérhető: http://www.hiia.hu/pub/displ.asp?id=HRIIHM (Letöltve: 2014.03.15.)

HuszKA BEÁTA (2013b): Történelmi egyezmény Észak-Koszovóról: az EUdiplomáciai sikere. MKI-Tanulmányok, 2013.04.26. 1-7. Elérhető: https://kki.hu/assets/upload/Elemzesek 201304 Terteenel mi egyezmeeny esza .pdf (Letöltve: 2020.01.27.)

HVG (2013): Szerbia hajlandó tárgyaláni Koszovó ENSZ-tagságáról. HVG, 2013.01.15.

Elérhetô:

http://hvg.hu/vilag/20130115 szerbia koszovo_ensz

(Letöltve: 2020.01.27.)

INDEX (2015): Több tízezren tüntettek a koszovói kormány ellen. Index, 2015.11.28.

Elérhető: http://index.hu/kulfold/2015/11/28/tobb tizezren tuntettek a koszovoi kormany ellen/ (Letöltve: 2020.01.27.) 
KITEKINTŐ (2011): További lépéseket vár az EU Szerbiától. Kitekintő, 2011.11.25. Elérhető: http://kitekinto.hu/karpatmedence/2011/11/25/tovabbi lepeseket var az eu szerbiatol/\#.U06q LV6el5Q (Letöltve: 2020.01.27.)

KITEKINTŐ (2014a): Szerbia tíz éven belül lezárhatja az uniós csatlakozási folyamatot.

Kitekintő, 2014.08.23. Elérhető: http://kitekinto.hu/europa/2014/08/23/szerbia tiz even bel ul lezarhatja az unios csatlakozasi folyamatot (Letöltve: 2020.01.27.)

KITEKINTŐ (2014b): Újabb lépést tehet Szerbia az EU felé. Kitekintő, 2014.11.20.

Elérhető: http://kitekinto.hu/karpatmedence/2014/11/20/ujabb lepest tehet szerbia az eu fele (Letöltve: 2020.01.27.)

KITEKINTŐ (2015): Az Európai Bizottság támogatja a szerbiai reformokat. Kitekintő, 2015.02.10. Elérhető: https://kitekinto.hu/karpatmedence/2015/02/10/az europai bizottsag tamogatja a szerbiai refo rmokat (Letöltve: 2020.01.27.)

KITEKINTŐ (2017): A feszültségek enyhítéséről tárgyalt Szerbia és Koszovó. Kitekintő, 2017.01.25.

Elérhető: http://kitekinto.hu/2017/01/25/europai-ugyek/afeszultsegek-enyhiteserol-targyalt-szerbia-es-koszovo/ 2020.01.27.)

(Letöltve:

Koszovó egyoldalú függetlenségének kikiáltásának a nemzetközi joggal való összhangjáról, no. 997, 2010. július 22-i tanácsadó véleménye a Nemzetközi Bíróságnak.

MATTSON, JENNIFER (2013): Serbia and Kosovo reach landmark deal. PRI, 2013.04.19. Elérhetô: https://www.pri.org/stories/2013-04-19/serbiaand-kosovo-reach-landmark-deal (Letöltve: 2020.01.27.)

MeHmeti, Jeton (2020): Kosovo: State-building in the Making. In. Dúró József - Egeresi Zoltán ed.: Political History of Balkans (1989- 2018). Budapest, Dialóg Campus.

Milanov ViKTor (2012): Szerbia fontos lépést tett az uniós tagság felé. Kitekintő, 2012.02.26.

Elérhető: http://kitekinto.hu/europa/2012/02/26/szerbia fontos lepes t tett az unios tagsag fele/\#.U0-hoF6el5R (Letöltve: 2020.01.27.)

Morina, Die (2015): Kosovo Hails Receipt of Own Telephone Code. Balkan Insight, 2015.12.15. Elérhető: http://www.balkaninsight.com/en/article/383-kosovo-s-dial-code-1215-2016 (Letöltve: 2020.01.27.) 
NAGY ORSOLYA (2013): A szerbek berobognak mellénk az unióba. Kitekintő, 2013.10.12.

Elérhetô: http://kitekinto.hu/europa/2013/10/12/a szerbek berobognak melle nk az unioba/ (Letöltve: 2020.01.27.)

NAGY Orsolya (2014): Unalmas kampány és előrelátható győzelem. Kitekintő, 2014.03.20. Elérhető: http://kitekinto.hu/europa/2014/03/20/unalmas kampany e s elre lathato gyzelem szerbiaban (Letöltve: 2020.01.27.)

ÖRDÖGH TIBOR (2019): Szerbia közeledése az Európai Unióhoz. In Koller Boglárka - Ördögh Tibor szerk.: Európaizáció a Nyugat-Balkánon. Budapest, Dialóg Campus Kiadó.

PANNONRTV (2013a): Nem feltétel Koszovó függetlenségének elismerése.

Pannon

RTV, 2013.07.02.

Elérhető: https://pannonrtv.com/rovatok/politika/nem-feltetelkoszovo-fuggetlensegenek-elismerese (Letöltve: 2020.01.27.)

PANNONRTV (2013b): Belgrádban üdvözlik az Ivica Dačić és Hashim Thaci közti egyezséget. Pannon RTV, 2013.09.10. Elérhető: https://pannonrtv.com/rovatok/politika/belgradban-udvozlik-az-ivicadacic-es-hashim-thaci-kozti-egyezseget-video (Letöltve: 2020.01.27.)

SZABAD MAGYAR SzÓ (2020): Júliusban folytatódhat a szerb-koszovói párbeszéd. Szabad Magyar Szó, 2020.06.23. Elérhető: https://szabadmagyarszo.com/2020/06/23/juliusbanfolytatodhat-a-szerb-koszovoi-parbeszed/ (Letöltve: 2020.10.02.)

SZILVÁGYI TiBOR (2012): Szerbia EU-integrációja Belgrád Koszovópolitikája tükrében. Biztonságpolitikai Szemle, 3. évf. 8. szám. 1-19. Elérhetô: $\quad$ https://docplayer.hu/11341717-Szerbia-eu-integraciojabelgrad-koszovo-politikaja-tukreben.html (Letöltve: 2020.01.27.)

VAJMA (2018): Vučić elrendelte a fokozott harckészültség feloldását. Vajdaság Ma, 2018.10.04.

Elérhető: https://m.vajma.info/cikk/szerbia/26305/Vucic-elrendelte-a-fokozottharckeszultseg-feloldasat.html (Letöltve: 2020.01.28.) 